\title{
BAB II \\ SIGNIFIKANSI TAURAT TUHAN DALAM MAZMUR 119: 97-106
}

\author{
Oleh : Ferdinan Pasaribu, S.Th \\ Afiliasi : Prodi Teologi, STT Ebenhaezer Tanjung Enim \\ Email : ferdinanmarcos1994@gmail.com
}

\begin{abstract}
:
A person who understands the significance of God's word will certainly love His laws as well as King David. Because the word of God always gives directions for King David's life. The love of the Law of God gave birth to a commitment for him to meditate on all day long. The significance of God's word is: First, the Giver of the word is Almighty God. Second, God's Word contains all the rules of life for all humans. Third, God's Word provides an intimacy between people and God. Fourth, the word of God can shape the character of life. That significance makes King David love the word of God. But, in fact, today there are many Christians who do not understand the significance of God's word so that Christians do not have the desire to love and meditate on the word of God. This condition is found in the Protestant Gospel Archipelago Church of Karang Anyar Lampung where the congregation does not yet understand the significance of God's word so that the congregation does not have a love of God's word. The church does not yet understand that the giver of the word is Almighty God. The church does not understand that the word of God reveals all the rules of life, intimacy and can shape character. Therefore, the church must understand the significance of God's word. If the church understands the significance of God's word, the church will love His words and keep all His laws.
\end{abstract}

\section{Abstrak :}

Seorang yang memahami signifikansi firman Tuhan tentu akan mencintai hukum-hukumNya seperti halnya raja Daud. Sebab firman Tuhan senantiasa memberikan petunjuk hidup bagi raja Daud. Kecintaan terhadap Taurat Allah melahirkan sebuah komitmen baginya untuk merenungkannya sepanjang hari. Signifikansi firman Tuhan ialah: Pertama, Pemberi firman adalah Allah yang Mahakuasa. Kedua, Firman Tuhan memuat segala aturan hidup bagi semua manusia. Ketiga, Firman Tuhan memberikan intimasi antara umat dan Allah. Keempat, firman Tuhan dapat membentuk karakter hidup. Signifikansi tersebutlah yang membuat raja Daud mencintai firman Tuhan.Akan tetapi, pada kenyataannya saat iniada banyak orang Kristen belum memahami signifikansi firman Tuhan, sehingga membuat orang Kristen tidak memiliki hasrat untuk mencintai dan merenungkan firman Tuhan. Kondisi ini didapati di Gereja Protestan Injil Nusantara Karang Anyar Lampung dimana jemaat belum memahami signifikansi firman Tuhan sehingga jemaat tidak memiliki kecintaan terhadap firman Tuhan. Jemaat belumlah memahami bahwa pemberi firman adalah Allah yang Mahakuasa. Jemaat belum memahami bahwa firman Tuhan menyatakan segala aturan hidup, sebuah intimasi dan dapat membentuk karakter. Oleh karena itu, jemaat haruslah memahami signifikansi firman Tuhan. Jika jemaat memahami signifikansi firman Tuhan, maka jemaat akan mencintai firman-Nya dan memelihara segala hukum-hukum-Nya.

Kata Kunci : Signifikansi, Mazmur, Taurat, Tuhan 


\section{Metode :}

Dalam penulisan karya ilmiah ini, penulis menggunakan metode deskriptifbibliologis, dengan menggunakan prinsip-prinsip hermeneutika agar dapat menemukan maksud dan makna dalam teks yang relevan dengan konteks saat ini. Penulis menggunakan metode tersebut oleh karena metode tersebut di dalam penyelesaiannya sesuai dengan permasalahan yang akan penulis teliti.

\section{PENDAHULUAN}

\section{PEMBAHASAN}

\section{Pengenalan Kitab Mazmur}

Judul kitab Mazmur dalam Bahasa Inggris "The Psalms."Septuaginta memakai kata "Psalmos", dalam Bahasa Ibrani "Mizmor" suatu istilah teknis untuk kidung yang dinyanyikan dengan iringan instrumen musik. Mazmur artinya nyanyian pujian.

Menurut hemat penulis, kitab Mazmur merupakan kumpulan pengalaman hidup dan pujian kepada Allah.Pengalaman para pelayan Tuhan yang digambarkan dengan ekspresi hidup, sebuah nyanyian dan pujian.

\section{Penulis Mazmur 119}

Ada beberapa tokoh yang menulis kitab Mazmur secara keseluruhan. Dalam Mazmur pasal 119 tidak ditulis nama pengarangnya, akan tetapi penulis Mazmur 119 adalah seorang yang percaya kepada Tuhan seorang yang mencintai firman Tuhan ${ }^{1}$ dan seorang yang memuji Taurat Tuhan. ${ }^{2}$ Matthew Henry berpendapat bahwa: "Mazmur 119 ini adalah kumpulan ucapan raja Daud". ${ }^{3}$ Tradisi Yahudi meyakini raja Daud sebagai penulis Mazmur 119. Mazmur 119 ditulis oleh raja Daud hendak menyatakan kekaguman dan memuji Firman Allah. ${ }^{4}$

\section{Profil Raja Daud Sebagai Penulis Kitab Mazmur 119}

Daud adalah anak bungsu Isai. ${ }^{5}$ Daud diuarapi Allah menjadi raja di Israel. ${ }^{6}$ Allah memilih Daud untuk menjadi raja di Israel. ${ }^{7}$ Daud dilukiskan sebagai seorang raja yang sangat percaya dan patuh kepada Taurat Allah. ${ }^{8}$ Kepemimpinan Daud dalam bidang

${ }^{1}$ Mazmur 119: 40, 53, 97

2 Marie Claire Barth dan B. A. Pareira, Kitab Mazmur 73-150, (Jakarta: BPK Gunung Mulia, 1999), 360

${ }^{3}$ Leslie F. Church and Gerald W Peterman, The NIV Matthew Henry Commentary In One Volume, (Grand Rapids, Michigan: Zondervan Publishing House, 1992), 733

4 Diakses 14 Maret 2018, Mazmur 119 - Wikipedia bahasa Indonesia, ensiklopedia bebas.html

${ }^{5}$ Rut 4: 22

${ }^{6}$ I Samuel 16: 1-13

${ }^{7}$ Daud adalah seorang raja teokratis, memerintah atas Yehuda di Hebron 7 tahun, 33 tahun di Yerusalemjuga menjadikan Yerusalem sebagai ibu kota kerajaan setelah mengalahkan orang Yebusi dan Yerusalem. T.H Jones (J.D Douglas, Edt), "Daud" Ensiklopedi Alkitab Masa Kini Jilid I: A-L, (Jakarta: Yayasan Komunikasi Bina Kasih/OMF, 1997), 240

8 David L Baker, Perjanjian Lama, (Jakarta: BPK Gunung Mulia, 2004), 66 
kerohanian Bangsa Israel membawa tabut perjanjian dari Kiryat-Yearim dan ditempatkan dalam Kemah Suci yang dibangun khusus di Yerusalem. Banyak dari peraturan keagamaan dalam kebaktian Bait Suci di kemudian hari, bermula pada susunan kebaktian dalam Kemah Suci, yang dibuat oleh Daud. ${ }^{9}$ Figur kepribadian Daud yang sangat luar biasa sebagai seorang raja dan pelayan Tuhan yang berkenan di hadapan Tuhan dipengaruhi oleh latar belakang kehidupan pribadinya, yaitu:

\section{Seorang Pengembala Domba Yang Diurapi Tuhan}

Allah mempersiapkan Daud untuk menjadi gembala bagi umat Allah. ${ }^{10}$ Daud memiliki hati gembala dan bijaksana dalam memimpin. Hati gembala yang dimiliki raja Daud lahir dari ketaatannya terhadap Taurat Tuhan. ${ }^{11}$ Allah memakai Samuel untuk mengurapi Daud dan Allah melimpahkan berkat kepada Daud. ${ }^{12}$ Daud mendapat urapan Allah oleh karena Daudtaat kepada Allah. ${ }^{13}$

\section{Daud Seorang Yang Berspiritualitas dan Rendah Hati}

Allah memilih Daud sebagai seorang raja oleh karena Daud memiliki spiritualitas yang baik dan kesungguhannya terhadap hukum-hukum Allah. ${ }^{14}$ Daud bersungguh hati untuk mencari Tuhan. ${ }^{15}$ Daud selalu merindukan untuk senantiasa dekat Allah. ${ }^{16}$ Daud senantiasa mencari Allah dan haus akan hadirat Allah. ${ }^{17}$

Allah melihat Daud sebagai seorang yang rendah hati, seorang yang setia dan taat kepada orang tua. ${ }^{18}$ Daud memiliki sikap hati yang selalu menghormati dan rindu mengangkat orang untuk berhasil. Hal inilah yang menjadi indikator bahwa Daud adalah seorang yang rendah hati. Daud senantiasa bergantung pada Allah. ${ }^{19}$ Kerendahan hati Daud tampak pada kebergantungannya kepada firman Allah. ${ }^{20}$

\section{Tujuan Penulisan Kitab Mazmur}

Adapun yang menjadi tujuan penulisan kitab Mazmur ialah:

a. Untuk memperlihatkan Allah sebagai pribadi yang mengenal jalan orang benar. ${ }^{21}$

b. Untuk mengungkapkan perasaan manusia dalam hubungan dengan Allah.

${ }^{9}$ Tradisi kuno menyebut Daud 'pemazmur yang disenangi di Israel' (II Samuel 23:1)

10 I Samuel 17: 15

${ }^{11}$ Mazmur 119: 97

${ }^{12}$ Daud diurapi Allah menjadi raja di Israel untuk menggantikan Saul memimpin Bangsa Israel. Meredith G. Kline (Donald Guthrie, Edit.), "Kejadian" Tafsiran Alkitab Masa Kini Jilid I, (Jakarta: Yayasan Komunikasi Bina Kasih/OMF, 2008), 138

13 I Samuel 16: 23

14 I Samuel 16: 7

15 II Samuel 12: 13

${ }^{16}$ Mazmur 62: 1-13

${ }^{17}$ Spiritualitas inilah yang dimiliki oleh Daud, kehidupan spiritualitas Daud sebagai seorang raja membuatnya hidup dalam pimpinan Tuhan. Mazmur 63: 63: 1-12

18 | Samuel 17: 17

19 I Samuel 17: 36-37

20 Kerendahan hati raja Daud tampak saat berhadapan dengan titah-titah Tuhan dan ketaatannya terhadap firman Tuhan. Kerendahan hati raja Daud membuatnya mengikuti perintahperintah Tuhan (Mazmur 119: 32)

${ }^{21}$ Mazmur 1: 6 
c. Untuk mengungkapkan kepercayaan, kasih, penyembahan, kerinduan akan persekutuan, kebesaran Allah yang menjadi alasan utama untuk dipuji dan disembah dan kuasa firman Tuhan yang memberikan kesalehan hidup dan kebahagaiaan. ${ }^{22}$

\section{Genre Kitab Mazmur 119}

Gunkel dalam penelitiannya menyatakan bahwa, "jenis sastra mazmur 119 ialah Mazmur hikmat". ${ }^{23}$ Genre ialah sebuah kelompok ayat-ayat yang sama dalam mood, isi, struktur atau susunan-susunan kata-katanya. ${ }^{24}$ Ada tujuh macam genre Mazmur: Mazmur pujian, Mazmur keluhan, Mazmur pengucapan syukur, Mazmur peringatan, Mazmur penyerahan, Mazmur raja, Mazmur hikmat. Setelah penulis meneliti teks Mazmur 119: 97-106 genre teks ini ialah Mazmur hikmat. J. Lawrence Eason mengatakan bahwa, "mazmur 119 adalah Psalms of wisdom."25 Menurut hemat penulis, Mazmur 119 merupakan kumpulan hikmat oleh karena memberikan nasihat hidup yang senantiasa membimbing setiap manusia berjalan dalam kebenaran Allah.

\section{Peranan kitab Mazmur Bagi Orang Yahudi}

Kitab Mazmur memberikan nasihat kepada umat Allah melalui firman-Nya dalam menyatakan sifat-Nya. ${ }^{26}$ Bagi konteks Yahudi dan non-Yahudi menilai bahwa kitab Mazmur penting dikarenakan:

Dalam kitab ini dicerminkan idealisme keagamaan yang saleh dan persekutuan dengan Allah, penyesalan karena dosa dan pencarian akan kesempurnaan, berjalan dalam kegelapan, tanpa ketakutan, oleh terang iman; tentang ketaatan kepada hukum Taurat Allah, gairah berbakti kepada Allah, persekutuan sesama pengikut Allah, penghormatan terhadap firman Allah; tentang kerendahan hati dibawah cambuk yang mengajar, kepercayaan yang teguh kendati kejahatan merajalela dan berjaya dan ketenangan ditengah-tengah kehampaan. ${ }^{27}$

\section{Keabsaahan Kitab Mazmur}

Penulis sangat mengimani bahwa kitab Mazmur merupakan kitab yang ditulis dalam Ilham Roh Kudus. Para Bapa Gereja meyakini bahwa semua yang tertulis dalam Alkitab adalah firman Allah. Demikian juga dengan Mazmur 119: 97-106 yang mengandung otoritas Ilahi yang mampu memberikan pemahaman dan mendidik setiap manusia menjadi benar dan bijaksana. Pakar teolog fundamentalis meyakini

22 Mazmur 150: 1-5

${ }^{23}$ W. S. Lasor, D. A Hubbard, F. W Bush, Pengantar Perjanjian Lama 2, (Malang: BPK Gunung Mulia, 2001), 42-58

24 Tremper Longman, Bagaimana Menganalisa Kitab Mazmur, (Malang: Seminari Alkitab Asia Tenggara, 1992), 10

220

${ }^{25}$ J. Lawrence Eason, The New Bible Survey, (Michigan: Zondervan Publishing House, 1963),

${ }^{26}$ Andrew E. Hill, Survei Perjanjian Lama (Malang: Gandum Mas, 2013), 435

27 J. D Douglas, Ensiklopedi Alkitab Masa Kini Jilid II, (Jakarta: Yayasan Komunikasi Bina Kasih, 1992), 41 
keabsahan Alkitab sebagai tulisan yang berotoritas yang tidak pernah bersalah (innerancy)..$^{28}$

\section{Analisis Mazmur 119: 97-106}

Teks mazmur 119 menyebarkan kebenaran dengan berlimpah-limpah."29 Mazmur 119 adalah suatu renungan tentang Taurat yang dipuji sebagai anugerah Tuhan yang paling berharga. Nada pengajaran terdengar dalam mazmur ini. Pemazmur tidak hanya membawa suatu teori melainkan menggemakan pengalaman pemazmur. Pemazmur bermaksud mengajak orang lain untuk mengikuti jalan yang serupa dan menyadari bahwa firman Tuhan adalah pelita yang menuntun hidup. Pada bagian ini penulis akan menguraikan analisa konteks teks; yaitu konteks sebelum Mazmur 119: 97-106, konteks dalam teks, konteks sesudah teks Mazmir 119: 97-106, konteks dekat dan juga konteks jauh.

\section{Konteks Jauh}

Analisa konteks jauh adalah menyelidiki konteks yang luas. Tujuan analisa konteks jauh ialah memaparkan uraian teks secara luas.

Nabi Ezra ialah seorang pelayan Allah yang mencintai Tuarat Tuhan. ${ }^{30} \mathrm{Hal}$ ini dilakukan oleh Ezra setelah memahami pentingnya Taurat Tuhan yang tidak bisa dikesampingkan dalam segala aspek. Taurat Tuhan yang mampu menuntun bangsa Israel. Hal yang senada ditegaskan oleh Rasul Paulus di dalam 2 Timotius 3: 16 bahwa iman bertumbuh dari pemahaman akan firman Tuhan. Paulus mengingatkan Timotius untuk mengajarkan firman Tuhan sebagai upaya melawan ajaran-ajaran palsu dan mendorong jemaat untuk mengalami pertumbuhan iman sekalipun berada dalam penganiayaan. Firman Allah memperlengkapi orang percaya menghadapi penganiayaan dan pengajaran sesat. Konteks Perjanjian Baru memberi penegasan bagi umat Allah bahwa memahami signifikansi adalah sebuah keharusan.

\section{Konteks Dekat}

Pada konteks dekat menunjukkan ayat-ayat yang berkisar sebelum dan sesudah teks yang ditafsirkan. Maka pada bagian ini, penulis akan menguraikan konteks dekat, dalam dan konteks sesudah Mazmur 119: 97-106.

\section{Konteks Sebelum Mazmur. 119: 97-106}

Konteks sebelum Mazmur 119: 97-106 menguraikan kebahagiaan seorang yang hidup menurut Taurat Tuhan. Taurat Tuhan memberikan kehidupan yang melimpah dengan kebahagiaan. ${ }^{31}$ Dalam teks ini menceritakan seorang raja yang hidup berkenan

28 Soetarman. Weinata Sairin. Ioanes Rakhmat, Fundamentalisme Agama-Agama dan Teknologi, (Jakarta: BPK Gunung Mulia, 1993), 18

29 David Powlison, Mengatakan Kebenaran Dalam Kasih, konseling Dalam Komunitas, (Surabaya: Momentum, 2011), 13

${ }^{30}$ Kecintaan Ezra terhadap taurat Tuhan tampak pada komitmen nya untuk meneliti taurat Tuhan dan melakukannya serta mengajar ketetapan dan peraturan di antara orang Israel (Ezra 7: 10)

${ }^{31}$ Yang dimiliki pemazmur sering diekspresikan dengan seorang yang menerima segala harta (Mazmur 119: 14) yang membuat Daud berkomitmen untuk merenungkan firman Tuhan (Mazmur 119: 15-16) 
dihadapan Allah. Banyak orang fasik disekeliling raja Daud pada masanya yang menghina Taurat Tuhan, akan tetapi Daud memiliki komitmen untuk terus hidup berdasarkan taurat Tuhan.

\section{Konteks Dalam Mazmur 119: 97-106}

Teks ini merupakan kumpulan puisi yang memuji Taurat. ${ }^{32}$ Teks ini diawali akan sebuah kekaguman, yaitu "Betapa kucintai Taurat-Mu! Aku merenungkannya sepanjang hari."33 Mazmur ini menekankan betapa Allah sudah memberitahukan kebenaran-Nya dalam komunikasi lisan seperti seorang guru terhadap murid dan orang tua terhadap anak melalui Taurat-Nya. Kebenaran itu dinyatakan dengan firman (dabar, imra). Peringatan-peringatan (edot) yang menekankan: bahwa Allah telah menyatakan diri-Nya dan tuntutan-Nya yang datang kepada manusia sebagai hukumhukum-Nya (huqqim). Dalam Mazmur ini, sangat tampak pujian dan kekaguman Daud terhadap Taurat Tuhan sebagai jalan untuk tetap berada dalam perkenaan Allah dan menerima berkat Allah.

\section{Konteks Sesudah Mazmur 119: 97-106}

Dalam keadaan yang sangat tertindas permohonan Daud kepada Tuhan menyatakan suatu pemahaman bahwa ketergantungan hidupnya hanya kepada Tuhan. Raja Daud menaikkan pujian sekalipun berada dalam pergumulan. Firman Tuhan menjadi milik pusaka untuk selama-lamanya. Kehidupan seorang yang sangat bergantung kepada firman-Nya menjadikanAllah sebagai pusat kehidupan. Faedah firman Tuhan akan membuar raja Daud merenungkan Taurat-Nya. Sehingga konteks teks Mazmur 119: 97-106 adalah lahirnya sebuah pujian dan kekaguman terhadap Taurat Tuhan.

\section{Hakikat Signifikansi Firman Tuhan Dalam Mazmur 119: 97-106}

Pada bagian ini, penulis menjelaskan hakikat signifikansi firman Tuhan. Pada teks yang penulis teliti ada beberapa istilah firman yang selalu diakhiri dengan akhiran "Mu". Allah dan firman-Nya adalah satu kesatuan yang tidak dapat dipisahkan. ${ }^{34}$ Kata firmanMu rb'D' (dabar) ditulis dalam bentuk noun common masculine singular construct suffix 2nd person masculine singular. Suffix merupakan kata penunjuk, dalam teks ini menunjuk pada pribadi "Mu" yaitu Allah sebagai pemilik dan pemberi firman. Dasar utama pentingnya firman Tuhan menurut Mazmur 119: 97-206, ialah:

\section{Pemberi Firman Tuhan Adalah Allah Yang Mahakuasa}

32 Ada delapan kata untuk taurat dalam mazmur ini: jalan, hukum, ketetapan, perintah, ketentuan, perkataan-perkataan, firman, titah. Sebuah pengalaman yang ada dalam taurat Tuhan. Dianne Bergant dan Robbert J. Karris, Tafsir Alkitab Perjanjian Lama, (Yogyakarta: Kanisius, 2002 ), 456

33 Mazmur 119: 97

${ }^{34}$ Allah tidak memisahkan hukum-Nya dengan diri-Nya, hukum Allah adalah perkataan-Nya yang terus-menerus dalam kehidupan Umat-Nya. J. I. Packer, Kristen Sejati Vol IV Sepuluh Hukum, (Jakarta: Lembaga Reformed Injili Indonesia, 1993), 68 
Allah yang memberikan seluruh hukum-hukum-Nya adalah Allah yang berkuasa atas segala tatanan dunia. Allah yang memberikan keselamatan danAllah yang senantiasa menolong dan memeliharan kehidupan Daud dan umat Allah. ${ }^{35}$

Kata "firman-Mu" dalam Bahasa Ibrani $\left.{ }^{\wedge} r<\right) b$ ' $D>$ (debarakh) ditulis dalam bentuk noun masculine singular suffix. Suffix artinya penunjuk, menunjuk pada pribadi "Mu" merupakan Allah Yahweh yang Mahakuasa. Pandangan penulis bahwa Allah Yahweh adalah pemberi firman. Firman Yahweh bukanlah perkataan yang mati, bukan sekadar pemaparan atas sesuatu yang tidakpasti terjadi.Harry Mowvley menuliskan bahwa, "Firman itu adalah perkataan Yahweh. Firman Yahweh bersifat pasti, sebab firman berasal dari Yahweh. ${ }^{36}$ Herlianto menegaskan bahwa firman Yahweh adalah perkataan yang hidup. ${ }^{37}$ Beberapa bukti kemahakuasaan Allah Yahweh yang menjadi dasar signifikansi firman Tuhan untuk dipahami Umat Allah:

\section{Allah Sebagai Pencipta dan Pemelihara}

Allah pencipta langit dan bumi adalah Allah yang Agung. ${ }^{38}$ Robert Letham menegaskan bahwaAllah membentuk bumi dengan firman-Nya. ${ }^{39}$ Allah berkuasa memelihara Daud dari cengkraman singa. ${ }^{40}$ Allah memelihara Daud dengan pertolongan dan kasih setia-Nya dan berkemah bagi orang-orang yang taku akan Tuhan. ${ }^{41}$

\section{Allah Yang Kekal dan Independen}

Daud menyadari bahwa Allah adalah pribadi yang Maha Agung dan kekal adanya. ${ }^{42}$ Allah yang memberikan firman-Nya merupakan pribadi yang telah ada sebelum permulaan dunia. Peter Vardy menuliskan: "Allah yang kekal adalah Allah tidak berawal mula". ${ }^{43}$ Daud menyadari bahwa Allah yang disembah merupakan pribadi yang independen, Allah yang memberikan hidup. ${ }^{44}$ Tony Evans menuliskan bahwa,

\footnotetext{
35 I Samuel 17: 37

${ }^{36}$ Harry Mowvley, Penuntun Ke Dalam Nubuat Perjanjian Lama, (Jakarta: BPK Gunung Mulia, 2000), 29-30

${ }^{37}$ Allah Yahweh adalah Allah Umat Israel.Allah Yahweh memiliki kuasa yang melaumpaui kuasa
} yang dimiliki manusia yang ada di muka bumi.YHWH artinya Tuhan yang ada dengan sendirinya dan Pribadi yang berkuasa bahkan yang lebih unggul dari berjuta-juta dewa di dunia. Nama Yahweh adalah "nama diri" sebenarnya terdiri 4 huruf konsonan YHWH yang disebut Tetragrammaaton dan dalam Alkitab Bahasa Indonesia Perjanjian Lama diterjemahkan sebagai TUHAN. Dalam perkembangannya nama Yahweh untuk menyebut nama Allah (Elohim, Adonai). Dalam tradisi naskah tua Pentateuch yang kemudian, agar nama Yahweh tidak esklusif hanya milik keturunan Abraham, nama diri Yahweh digunakan juga sebagai nama Tuhan pada zaman Enos (Kej. 4: 26). Herlianto, Siapakah Yang Bernama Allah Itu? , (Jakarta: BPK Gunung Mulia, 2005), 17-20

${ }^{38}$ Kejadian 2: 4Kolose 1: 16; Ibrani 1: 2

${ }^{39}$ Hanya Allah yang hidup, Allah yang dapat menciptakan dunia serta manusia.itulah Allah yang memberikan firman-Nya. Allah Yahweh juga hadir sebagai oknum yang memelihara dan menyediakan setiap kebutuhan manusia dengan penuh kasih setia-NyaRobert Letham, Allah Trinitas: Dalam Alkitab, Sejarah, Theologia, dan Penyembahan, (Surabaya: Momentum, 2011), 17

40 I Samuel 17: 37

41 Mazmur 65 ; Mazmur 34: 8

42 Mazmur 90: 1-2

${ }^{43}$ Peter Vardy, Allah Para Pendahulu Kita, (Jakarta: BPK Gunung Mulia, 1992), 13

44 Mazmur 33: 9 ; 104: 29-30 
"Allah tidak membutuhkan sesuatu dari luar diri-Nya untuk menciptakan alam semesta ${ }^{45}$

R. C. Sproul mengatakan:

Allah yang memberikan firman kepada umat-Nya adalah Pribadi yang benar, kudus, di dalam Allah tidak terdapat kesalahan dalam segala keadaan. Allah adalah "Summum Bonum" Allah adalah ukuran dari segala kesempurnaan, norma dari segala etika, mata air dari segala kehidupan. Tidak sesuatupun yang lebih tinggi dariNya.Allah adalah Pribadi yang mengadili semua manusia dengan keadilan-Nya. ${ }^{46}$

Jadi, dasar inilah yang membuat Daud mencintai firman Allah, sebab Allah yang memberikan firman adalah Allah yang kekal dan ada dengan sendirinya. ${ }^{47}$

\section{Allah Yang Tidak Terbatas dan Allah Yang Berdaulat}

Dasar Daud mengatakan bahwa Allah adalah pribadi yang berkuasa ialah bukti pemeliharaan Allah dan kedaulatan Allah atas dunia. Bagi Daud Allah adalah gunung keselamatan dan perisai hidup. ${ }^{48}$

Millard J. Erickson menuliskan:

Ketidak terbatasan Allah dapat dipandang dari berbagai segi: Pertama, dari segi ruang, bahwa Allah dapat ditemukan pada semua ruang di dunia ini. Allah juga tidak terbatas dalam hubungan dengan waktu. Kedua, Allah senantiasa ada. Ketiga, Allah memiliki pengetahuan yang mampu mengetahui perjalanan hidup yang ada di dunia, la Allah yang bijaksana. ${ }^{49}$

Allah berdaulat melakukan apa yang dikehendaki-Nya, sebab semua yang ada di dunia adalah milik-Nya. ${ }^{50}$ Allah memiliki otoritas melakukan segala sesuatu yang menjadi kehendak-Nya. ${ }^{51}$ Allah sanggup melakukan segala sesuatu.Panggilan "Yahweh" (Jehovah) menekankan Kemahakuasaan dan sifat-sifat Allah, diantaranya: Allah adalah pemberi keselamatan (Jehovah Shalom). ${ }^{52}$ Allah penopangalam semesta (Jehovah Tsebaoth). ${ }^{53}$ Allah pemberi kesembuhan (Jehovah Rapha). ${ }^{54}$

\section{Firman Tuhan Mengandung Aturan Dasar Serta Pengingat Hidup Sebagai Umat Allah}

${ }^{45}$ Tony Evans, Teologi Allah, (Malang: Gandum Mas, 1999), 54-56

${ }^{46}$ R. C. Sproul, Sifat Allah, (Jakarta: BPK Gunung Mulia, 2002), 115-119

${ }^{47}$ Mazmur 24: 1; Yes. 41: 4

48 Mazmur 62

49 Millard J. Erickson, Teologi Kristen, (Malang: Gandum Mas, 1999), 353-359

${ }^{50}$ Mazmur 24: 1

${ }^{51}$ Ayub 23: 13

52 Habakuk 6: 24

53 I Samuel 1: 3

${ }^{54}$ Keluaran 15: 26 
Istilah firman Tuhan dalam mazmur 119 menggunakan beberapa kata, yaitu Perintah-Mu, Peringatan-Mu, Firman-Mu, Hukum-hukum-Mu, Janji-Mu, Taurat-Mu, Pelita-Mu.

\section{Intruksi Bersumber Dari Allah Yang Mahakuasa Serta Sebagai Dasar Hidup}

Allah memberikan aturan dasar hidup kepada umat-Nya untuk mengingatkan umat bagaimana hidup dihadapan Allah. Aturan dasar tersebut bersumber dari Allah yang Mahakuasa. Allah mengingatkan umat-Nya dengan memberikan intruksi berdasarkan firman-Nya. Istilah intruksi dalam teks ini digambarkan pada kata "perintah-Mu".

Kata "perintah-Mu" dalam Bahasa Ibrani ${ }^{\wedge} \mathrm{t}<+$ wOc.m (misewot) commandments ditulis dalam bentuknoun feminime plural construct suffix. ${ }^{55}$ Kata ${ }^{\wedge} \mathrm{t}<+w O c . m i$ (misewot) dalam bentuk construct merupakan sebuah tindakan yang dilakukan dengan sungguh-sungguh. Suffix merupakan kata penunjuk yang menunjuk kepada Allah sebagai pemberi perintah dan pemilik firman. Dalam NIV memakai kata commands ${ }^{56}$ dalam NASB memakai kata commandsments. ${ }^{57}$ Dalam TWOT kata ${ }^{\wedge} \mathrm{t}<+$ wOc.mi (misewot) memiliki pengertian (judgment, govern, justice hukum, custom, manner. Dalam konteks orang Yahudi istilah perintah-Mu digunakan untuk instruksi seorang ayah kepada seorang anak. ${ }^{58}$

Kata "perintah-Mu" menggambarkan sebuah instruksi, kemudian menggambarkan pemenuhan perintah Allah Israel. ${ }^{59}$ Tuhan menjamin kebenaran firman-Nya dengan perintah-Nya. ${ }^{60}$ Istilah govern sendiri menjelaskan sebuah kekuasaan yang memerintah secara keseluruhan. ${ }^{61}$ Sehingga kata perintah-Mu mengacu kepada peraturan dan ketetapan yang mengungkapkan peraturan Allah yang berkuasa atas kehidupan yang patut ditaati. Perintah Allah mengandung janji dan otoritas dari semua perintah. Perintah Tuhan adalah dasar kehidupan yang mengandung isi hati Allah dan mengingatkan hidup semua umat Allah. Di dalam perintah Tuhan tersirat semua peraturan dan ketetapan-ketetapan Allah. Maka, makna kata perintah-Mu merupakan ungkapan sebuah keseluruhan aturan dasar hidup sebagai umat Allah.

\section{Firman Allah Memberikan Nasihat Hidup Sebagai Umat}

Allah senantiasa memberikan nasihat, baik kepada Bangsa Israel, nabi-Nya, imam-Nya maupun kepada umat manusia. Tujuan Allah memberikan nasihat agar

875

55 John Joseph Owens, Analytical Key to the Old Testament Vol 3 Ezra-Song Og Salomon, 480

${ }^{56}$ Kenneth Barker, The NIV Study Bible New International Version, 919

${ }^{57}$ Lockman Foudation, New American Standard Bible, (Califirnia: J. B. McCabe Company, 1977),

${ }^{58}$ R. Laird Harris, Gleason L. Archer and Bruce K. Waltke, Theological Wordbook Of The Old Testament, (Chicago: The Moody Bible Institute, 1980), 948

${ }^{59}$ Keluaran 25-30; Keluaran 36-39; Imamat 8

60 Tuhan akan memerintahkan berkat bagi mereka yang setia kepada perintah-Nya.Mazmur 105: 8; 111: 9; Mazmur 133: 3; Ulangan 28:

61 Jhon M. Echols dan Hassan Shadily, Kamus Inggris-Indonesia, (Jakarta: PT Gramedia, 1982), 
umat berjalan berdasarkan aturan, hukum, dan kehendak-Nya. Dalam teks ini, istilah nasihat digambarkan pada kata peringatan-Mu.

Kata "peringatan-Mu" dalam Bahasa Ibrani ${ }^{\wedge} \mathrm{yt}^{\mathrm{a}} \mathrm{wOd}>[\mathrm{e} \div$ (eduwth) ditulis dalam bentuk conjunctive noun feminime plural suffix. ${ }^{62}$ Kata ${ }^{\wedge} \mathrm{yt}{ }^{\mathrm{a}} \mathrm{wOd}>[\mathrm{e} \div$ (eduwth) berasal dari kata dasar tWd[e (edut) artinya: kesaksian, nasehat, teguran dari Tuhan, peraturan, peringatan. ${ }^{63}$ Merupakan kata benda penghubung dalam bentuk jamak atas semua peringatan-Nya. Suffix adalah kata penunjuk yang menunjuk kepada Allah sebagai pemberi firman. Dalam NIV memakai kata undang-undang, aturan dasar. ${ }^{64}$ Kata ${ }^{\wedge} \mathrm{yt}^{\mathrm{a}} \mathrm{wOd}>\left[\mathrm{e} \div\right.$ (eduwth) dalam TWOT ialah testimony, reminder, warning sign. ${ }^{65}$

Jadi, kata Peringatan menyatakan sebuah syarat-syarat, tuntutan-tuntutan, nasihat perjanjian yang dinyatakan sebagai kehendak Allah. Ungkapan peringatan-Mu menunjukkan prinsip-prinsip dan sarana operasional atau anggaran dasar, aturan dasar yang dengannya Allah berhubungan dengan umat-Nya dengan memberikan nasihat-Nya. Nasihat Allah selalu mendidik semua manusia. Allah mendidik umat-Nya berdasarkan peringatan-Nya yang memuat segala prinsip-prinsip hidup sebagai umat Allah. Tujuan Allah memberikan peringatan-Nya ialah agar umat-Nya memahami segala aturan dasar hidup sebagai umat Allah. Umat Allah haruslah berjalan berdasarkan peringatan Allah yang memberikan nasihat untuk hidup dalam kehendak Tuhan.

\section{Kebenaran Allah Merupakan Dasar Menjalani Hidup}

Alkitab memberi kesaksian bahwa sesungguhnya Allah adalah kebenaran. ${ }^{66}$ Kebenaran Allah menuntun manusia berjalan pada jalan-Nya, menuntun manusia untuk hidup dalam kebenaran-Nya dan kekudusan hidup. Allah dan firman-Nya adalah kesatuan yang tidak dapat dipisahkan. Dalam teks ini, istilah kebenaran memakai kata firman-Mu $\left.{ }^{\wedge} r<\right) b^{\prime} D>$ (debarekhak).

Kata "firman-Mu" dalam Bahasa Ibrani $\left.{ }^{\wedge} r<\right) b ' D>$ ditulis dalam bentuk noun masculine singular suffix berasal dari kata dasar rb'D' (dabar) perkataan, nasihat, jawaban, perintah, perhatian, arahan, panduan, pesan, kewajiban. ${ }^{67}$ Kata rb'D' memiliki beberapa arti, yaitu word, speaking, speech, thing, anything, everything, nothing negatives. ${ }^{68}$ Sifat dari kata rb'D' ialah perkataan yang di dalamnya tidak ada kebohongan atau kepalsuan. ${ }^{69}$ Sehingga esensi kata firman-Mu merupakan penyataan

62 John Joseph Owens, Analytical Key to the Old Testament Vol 3 Ezra-Song Og Salomon, 480

63 Robert L Thomas, New American Standard Exhaustive concordance of the Bible HebrewAramic and Greek Dictionaries, (Tennessee: The Lockman Foundation, 1977), 1570

${ }^{64}$ Kenneth Barker, The NIV Study Bible New International Version, 919

${ }^{65}$ R. Laird Harris, Gleason L. Archer and Bruce K. Waltke, Theological Wordbook Of The Old Testament, (Chicago: The Moody Bible Institute, 1980), 648

66 Yohanes 14: 4-6

67 John Joseph Owens,..., Analytical Key to the Old Testament Vol 3 Ezra-Song Og Salomon, 480

${ }^{68}$ R. Laird Harris, Gleason L. Archer and Bruce K. Waltke, Theological Wordbook Of The Old Testament, (Chicago: The Moody Bible Institute, 1980) 180

69 Kata yang dipakai di dalam Perjanjian Lama bagi firman adalah דָָר (Dabar). Kata "Dabar" berarti perkataan, akan tetapi bukan perkataan yang kosong. "Dabar" adalah perkataan yang telah 
diri Allah secara umum atas semua perintah serta janji-Nya yang mengandung semua aturan-aturan hidup. Kata rb'D' (dabar) merupakan perkataan yang telah berisikan latar belakang atau dasar yang terkandung di dalam perkataan itu. Sifat terpenting dari kata firman ialah kebenaran Allah. Sehingga tanpa firman-Nya manusia tidak akan memahami hukum-hukum Tuhan, ketetapan-ketetapan, perintah-perintah-Nya. Jika sebagai umat tidak memahami firman-Nya, maka umatakan berjalan dalam kekeliruan. Jadi, ungkapan firman-Mu adalah sebuah kebenaran yang absolute tentang Allah dan semua kehendak-Nya.

\section{Firman Allah Menyatakan Pola Hidup Sebagai Umat}

Hukum Allah merupakan dasar hidup yang mengarahkan manusia berjalan berdasarkan peraturan-Nya. Manusia yang berjalan berdasarkan aturan-Nya senantiasa berada dalam perkenanan Allah. Hukum-hukum Allah memberikan pola hidup sebagai umat Allah. Dalam teks ini pola Allah termuat dalam hukum Allah. Istilah hukum-Mu memakai kata ^^yj,îP'v.Mimi (mishpat).

Kata "hukum-Mu" dalam Bahasa Ibrani ^yj,îP'v.Mimi (mishpat) ditulis dalam bentuk preposition noun masculine plural suffix (ordinances) ${ }^{70}$ berasal dari kata dasar jP'V.mi pendapat, keputusan, pertimbangan, keadilan, peraturan, penyataan, tatakrama, kebenaran, ukuran dasar, norma, syarat. ${ }^{71} \mathrm{~J}$. I. Packer berpendapat:

Manusia wajib belajar dari hukum-hukum Allah, oleh karena, Pertama, Terdapat perintah llahi yang mewahyukan pikiran dan hati Allah untuk segala jaman. Kedua, Allah menginginkan Umat-Nya menjadi manusia yang sejati. Dalam hokum-hukum-Nya dijelaskan tindakan-tindakan apa yang Allah benci dan sikap yang Allah harapkan. Ketiga, Hukum-hukum-Nya memberikan petunjuk jenis pola hidup yang bagaimana, yang sunggug-sungguh tepat dan kodrati bagi Umat.Keempat, Hukum-hukum Tuhan menunjukkan siapa kita dihadapan Allah. ${ }^{72}$

Dengan demikian, hukum Allah merupakan seluruh peraturan dasar Allah kepada umat-Nya. Maka umat Allah haruslah berlaku sesuai dengan ukuran dasar yang telah Allah tetapkan di dalam hukum-hukum-Nya. Di dalam hukum-hukum-Nya, Allah mengekspresikan sifat-sifat-Nya, juga memperingatkan manusia akan segala hal yang Allah kehendaki. Hukum Allah memberikan pola hidup suci dan pengabdian kepada Allah. Hukum Allah merupakan pola yang memberikan petunjuk hidup sejati yang

berisikan latar belakang atau dasar yang terkandung di dalam perkataan itu. Kata "Dabar"senantiasa cocok dengan perkara yang diungkapkan di dalam perkataan itu. Oleh karena itu sifat terpenting dari kata "Dabar" ialah "kebenaran". rb'D'.Robert L Thomas, New American Standard Exhaustive concordance of the Bible Hebrew-Aramic and Greek Dictionaries, (Tennessee: The Lockman Foundation, 1977), 1507

70 John Joseph Owens,..., Analytical Key to the Old Testament Vol 3 Ezra-Song Og Salomon, 480

${ }^{71}$ Robert L Thomas, New American Standard Exhaustive concordance of the Bible HebrewdAramic and Greek Dictionaries, 1557

72 J. I. Packer, Kristen Sejati Vol IV Sepuluh Hukum, (Jakarta: Lembaga Reformed Injili Indonesia, 1993), 67-69 
senantiasa mengarahkan manusia berjalan dalam ketentuan-ketentuan Allah. Di dalam hukum-hukum Allah memuat segala peraturan-peraturan, undang-undang-Nya.

\section{Pengharapan Kepada Allah Merupakan Kekuatan Hidup Umat Allah}

Dalam konteks kehidupan raja Daud tampak sebuah spiritualitas. Spiritualitas raja Daud tampak dari sikap hidup yang senantiasa berharap pada janji Allah. ${ }^{73}$ Dalam teks ini istilah pengharapan menggunakan kata ${ }^{\wedge} \mathrm{t},{ }^{\mathrm{a}} \mathrm{r} " \mathrm{~m}$.ai (imerakh). ${ }^{74}$

Kata "janji-Mu" dalam Bahasa Ibrani ${ }^{\wedge} t,{ }^{a}{ }^{a}$ "m.ai (imerakh) ditulis dalam bentuk noun feminime singular ord 2 suffix. ${ }^{75}$ Kata ${ }^{\wedge} t,{ }^{a}{ }^{\prime \prime}$ m.ai memberi penjelasan Allah sebagai pemberi janji. Daud berdiri sebagai subjek yang percaya pada janji Allah. Kata ${ }^{\wedge}{ }{ }^{a}{ }^{2}$ "m.ai (imerakh) dalam TWOT memiliki pengertian utterance, speech, word, saying, promise. Istilah ${ }^{\wedge} \mathrm{t},{ }^{a}{ }^{\prime \prime}$ m.ai menunjuk pada janji Allah kepada Daud untuk memiliki tanah perjanjian. ${ }^{76}$ Ungkapan janji merupakan pernyataan komitmen atau kesepakatan Allah kepada Daud dan umat-Nya dimana Allah tidak dapat mengingkarinya. Janji yang berasal dari Allah merupakan sebuah pengharapan yang memberikan kenikmatan hidup bagi raja Daud dan manusia. Bagi raja Daud janji Allah lebih manis dari madu. ${ }^{77}$ Janji-Nya yang membuat umat Allah cinta kepada firman-Nya. Janji-Nya adalah harapan bagi umat Allah. Di dalam janji-Nya terdapat pertolongan Allah yang nyata. Janji Allah mampu menolong umat Allah untuk senantiasa hidup dan percaya kepada Sang pemberi janji yaitu Allah Yahweh, sehingga dalam janji Allah terdapat sebuah kepastian.

\section{Pengajaran Yang Bersumber Dari Allah Adalah Dasar Menjalani Hidup}

Allah menberikan firman-Nya untuk mengajar umat-Nya. Allah memberikan sepuluh hukum merupakan dasar hidup dan pengajaran. ${ }^{78}$ Taurat Allah menyatakan sebuah pengajaran yang menuntun, mengarahkan, memimpin kehidupan. Dalam teks ini istilah pengajaran memakai kata Taurat-Mu.

Kata "Taurat-Mu" dalam terjemahan Bahasa Ibrani ${ }^{\wedge} t<+r^{\prime \prime} A t$ (towrah) dari kata dasar hr'AT (towrah) ${ }^{79}$ ditulis dalam bentuk noun feminime singular suffix. Merupakan kata benda yang menunjuk pada ajaran-ajaran yang berasal dari Allah Yahweh. Kata "Taurat-Mu" dalam terjemahan KJVmemakai kata law yaitu: hukum, dalil, alat-alat hukum, undang-undang. Dalam terjemahan NASB menggunakan kata hukum. Arti kata

${ }^{73}$ Mazmur 145

74 Jay P. Green, The Interlinier Hebrew-Aramic Old,..., 1508

75 John Joseph Owens, Analytical Key to the Old Testament Vol 3 Ezra-Song Og Salomon,

${ }^{76}$ Segala yang telah difirmankan Allah dengan mulut-Nya, dapat dan akan dilakukan-Nya, itulah ciri khas Allah menurut Alkitab, sebab firman-Nya tidak akan kembali kosong. Berbeda dari manusia dan ilah-ilah orang kafirR. Laird Harris, Gleason L. Archer and Bruce K. Waltke, Theological Wordbook Of The Old Testament,..., 55

${ }^{77}$ Mazmur 119: 103

${ }^{78}$ Keluaran 20

79 John Joseph Owens,.., Analytical Key to the Old Testament Vol 3 Ezra-Song Og Salomon,..., 
hr'AT (towrah) dalam TWOT ialah lae, teaching, sometimes teaching, instruction, decsions. ${ }^{80}$

Istilah hora berarti: memimpin, mengajar, mendidik, dan pengajaran. David M. Howard Jr menuliskan: "Pembacaan Kitab suci sama pentingnya dengan mempersembahkan korban". ${ }^{81}$ Hukum Taurat menyatakan sifat hubungan antara Allah dengan umat-Nya. Hukum Taurat mengajarkan sikap hidup kepada Allah maupun manusia. ${ }^{82}$ Jadi, hukum Taurat tidak dimaksudkan hanya sebagai seperangkat peraturan. Pemberian hukum Taurat bertujuan untuk menolong manusia tetap dalam perkenanan Allah dan membuat hidup lebih bijaksana.

\section{Dasar Menjalani Hidup Sebagai Umat Allah Terletak Pada Cahaya Firman}

Alkitab menyatakan bahwa cahaya Allah menuntun dan membuat manusia tidak tersandung. Cahaya firman Allah memberikan kehidupan. ${ }^{83}$ Manusia yang berjalan berdasarkan cahaya Allah akan disebut berbahagia. ${ }^{84}$ Setiap orang yang berjalan berdasarkan cahaya firman disebut sebagai orang benar. ${ }^{85}$ Dalam teks ini, istilah cahaya memakai kata pelita.

Kata "Pelita"dalam Bahasa Ibrani $r A a^{a} w>\div$ (owr) ditulis dalam bentuk noun common both singular absolute, a lamp (lampu), a light (terang), candle (lilin). Kata benda yang menyatakan kemutlakan. Istilah "terang" menggunakan kata rAa conjunction noun masculine singular ${ }^{86}$ yang memiliki arti and a light (dan terang, cahaya, sinar, keterangan, sumber cahaya) ${ }^{87}$

Kata $\mathrm{rAa} a^{\mathrm{a}} \mathrm{W}>\div$ dalam TWOT "light"cahaya berkaitan erat dengan kehidupan dan kebahagiaan, yang mungkin menjelaskan perbandingan yang sering terjadi antara Allah dan terang. Cahaya menunjuk pada kemuliaan Tuhan. ${ }^{88}$ Daud menyadari bahwa firman Allah mampu menyinari hidup sekalipun berada dalam kegelapan. ${ }^{89}$ Firman yang tertulis jika direnungkan memberikan penerangan dan cahaya yang memberikan arah kepada semua manusia. Membuka pengertian, pemahaman kehendak Allah yang membuat umat Tuhan menghindari jalan yang menuju kegelapan. Perjalanan hidup rohani raja Daud dibimbing oleh cahaya firman Allah, sehingga dasar ini yang membuat raja Daud memahami signifikansi firman Tuhan.

\footnotetext{
${ }^{80}$ R. Laird Harris, Gleason L. Archer and Bruce K. Waltke, Theological Wordbook Of The Old Testament, .., 403

81 Kata Ibrani yang biasanya untuk menerjemahkan torah memiliki arti pengajaran atau petunjukDavid M. Howard Jr, Kitab-Kitab Sejarah Dalam Perjanjian Lama, (Malang: Gandum Mas, 2002) 383

82 Hukum Taurat berisikan ajaran, yang menyampaikan pewahyuan Ilahi, baik untuk menerangi budi, maupun untuk mengarahkan hidup manusia. William Dyrness, Tema-Tema Dalam Teologi Perjanjian Lama (Malang; Gandum Mas, 2001), 109-111

${ }^{83}$ Mazmur 56: 13

${ }^{84}$ Mazmur 89: 15

${ }^{85}$ Amsal 4: 18

86 Ibid, ..., 481

${ }^{87}$ Spiros Zodhiates, The Hebrew-Greek Key Study Bible New American Standard,..., 818

${ }^{88}$ Cahaya melambangkan hidup atau kemakmuran. Cahaya sejajar dengan sumber kehidupan Mazmur 77: 18; 97: 4; Ayub 36:32

892 Samuel 22: 29
} 
Dengan demikian, Daud menyadari hanya terang firman Tuhan yang dapat menyelamatkan hidup. Firman Tuhan adalah pelita dan terang yang menjadi sumber cahaya. Cahaya yang mampu memberikan penerangan ditengah kegelapan. Taurat Tuhan adalah pelita yang menuntun seseorang untuk berjalan dalam terang Allah. Jelas bahwa orang yang setia terhadap Taurat tidak akan berjalan dalam kegelapan karena terang itu selalu menuntunnya untuk melakukan hal-hal yang suci, bersih, dan benar di hadapan Allah. John Piper mengutip penyataan Edwards "Saya berpandangan bahwa Firman Allah mengajar kita lebih banyak hal tentang realitas Ilahi yang mulia dan Firman Allah menunjukkan banyak perkara tentantang realitas Ilahi jauh lebih mulia dan ajaib daripada yang telah diperhatikan". ${ }^{90}$ Cahaya firman sangatlahmenentukan pola hidup rohani orang Kristen, sebab hanya firman Tuhan yang mampu menerangi kegelapan, Orang yang percaya seyogyanya harus menempatkan diri dalam disiplin rohani dengan menjadikan firman Tuhan sebagai cahaya kehidupan.

\section{Firman Tuhan Memberikan Intimasi Antara Umat Dan Allah}

Kebenaran firman Allah memberikan intimasi atau hubungan antara umat dan Allah.Intimasi tersebut tampak kepada kehidupan yang senantiasa mencintai firman Tuhan, senantiasa berkomunikasi kepada Allah, dan memiliki keyakinan yang teguh kepada Allah.

\section{Mengungkapkan Sebuah Hubungan dan Perasaan Yang Dalam Terhadap Allah (Ay. 97)}

Daud sangat mencintai firman Tuhan, oleh karena firman Tuhan membawa Daud kepada hidup yang senantiasa intim dengan Allah. Kesukaan raja Daud terhadap Taurat Tuhan merupakan wujud seorang memiliki hubungan atau keintiman dengan Allah. Dalam teks ini Daud mengungkapkan rasa cintanya terhadap Taurat Tuhan.

Kata "kucintai" dalam terjemahan Bahasa Ibrani yTib.h;îa'-hm'( berasal dari kata dasar bha verb qal perfect 1 st person common singular. ${ }^{91}$ Kata kerja aktiv yang dilakukan secara sempurna. Daud sebagai subyek utama yang mencintai Taurat Tuhan. Dalam terjemaham KJV menggunakan kata cinta, asmara, kasih kepada Allah kasih sayang. ${ }^{92}$ Kata bha dalam terjemahan TWOT ialah love, lovely, lovers, love gifts. ${ }^{93}$ Istilah bha (ahab) dalam buku word studies memberikan pengertian:

Mencintai yang di dalamnya seseorang menyukai, atau yang sangat ia inginkan.

Ini menyiratkan kecenderungan yang bersemangat dan bersemangat atau pikiran,

${ }^{90}$ Firman Tuhan mampu memberikan terang dalam langkah-langkah kehidupan kita.Firman Tuhan berkuasa memperbarui hidup dan memberikan kekuatan baru di dalamnya. John Piper, Gairah Allah Bagi Kemuliaan-Nya, (Surabaya: Momentum, 2008), 11

91 , Lembaga Alkitab Indonesia, Perjanjian Lama Ibrani-Indoneisia, (Jakarta: Lembaga Alkitab Indonesia, 2002), 1205

${ }^{92}$ Kenneth Barker, The NIV Study Bible New International Version, (Michigan Grand rapids: Zondervan Publishing House), 919

${ }^{93}$ R. Laird Harris, Gleason L. Archer and Bruce K. Waltke, Theological Wordbook Of The Old Testament, 14 
pada saat bersamaan adalah kelembutan dan kepenuhan kasih sayang, dan dianggap sama dengan kata "cinta" dan digunakan untuk cinta yang tak terkatakan dan belas kasihan yang lembut dari Allah. ${ }^{94}$

Dalam ayat ini Daud mengungkapkan sebuah hubungan dan perasaan yang dalam terhadap Allah. Raja Daud menyadari dan memahami betapa pentingnya pengajaran Allah yang tertulis di dalam Taurat Tuhan, sehingga Daud memelihara keintimannya dengan Allah melalui firman-Nya. Mencintai firman Tuhan bukanlah sebuah paksaan, bukan sebuah kewajiban semata dan bukan pula beban, melainkan sebuah kesukaan yang didasari sebuah perasaan yang mendalam. Raja Mengapa Daud jatuh cinta sedemikian dalam? Daud menemukan begitu banyak hal yang membuktikan keampuhan firman Tuhan, diantaranya: Daud menyadari bahwa firman Tuhan memberi kehidupan. ${ }^{95}$ Firman Tuhan membuatnya lebih bijaksana dan beraskal budi. ${ }^{96}$ Daud menjadi lebih paham dari orang-orang tua yang bijaksana sekalipun. ${ }^{97}$ Memberikan kemampuan menahan diri dari segala godaan dunia. ${ }^{98}$ Ada janji yang manis yang mampu memberikan penghiburan dikala susah. ${ }^{99}$ Firman Tuhan memberi pengertian sehingga Daud memahami bahwa Allah membenci dosa. ${ }^{100}$ Firman Tuhan mampu mengarahkan masa depannya kearah yang diinginkan Tuhan. ${ }^{101}$

\section{Memberikan Komunikasi Yang Intensif (Ay. 97)}

Keintiman raja Daud kepada Allah tampak pada aktivitas Daud yang senantiasa merenungkan Taurat Tuhan. Konteks pada waktu itu, Daud dikelilingi oleh orang-orang fasik yang hendak mencelakakan hidupnya. ${ }^{102}$ Sikap raja Daud dalam menghadapi orang-orang fasik ialah berkomunikasi kepada Tuhan melalui firman-Nya. Istilah komunikasi dalam teks ini menggunakan kata merenungkan.

Kata "merenungkan" dalam Bahasa Ibrani yti(x'yfi (siyhati) dari kata dasar hx'yfi (siychah) ditulis dalam bentuk adjective feminime common singular construct suffix. ${ }^{103}$ Adjective berarti kata sifat. Kata "merenungkan" dalam NIV merencanakan, bersemedi. ${ }^{104}$ Daud merenungkan Taurat Tuhan secara sungguh-sungguh setiap waktu. Daud merenungkan perbuatan Tuhan yang tertulis dalam Taurat-Nya. Arti kata yti(x'yfi dalam TWOT ialah I meditate, muse, commune, speak, complain, prayer,

\footnotetext{
${ }^{94}$ Wilsons, Old Testament Word Studies, (Peabody: Hendrickson Publishers), 260

95 Mazmur 119: 93

${ }^{96}$ Mazmur 119: 98; Mazmur 119: 99

${ }^{97}$ Mazmur 119: 100

98 Mazmur 119: 1-1

99 Mazmur 119: 103

100 Mazmur 119: 104

101 Mazmur 119: 105

102 Mazmur 119: 42a , 51, 54

103 John Joseph Owens, Analytical Key To The Old Testament,..., 480

${ }^{104}$ Kata hx'yfi berasal dari kata kerja yang pada dasarnya sama artinya, yaitu, meditasi, keluhan, berbicara, komunikasi, doa. Spiros Zodhiates, Key Word Study Bible,..., 719
} 
talking, communication, babbling. devotion. Kata yti(x'yfi (siyhati) muncul empat belas kali dalam Perjanjian Lama. ${ }^{105}$ Daud senantiasa memikirkan firman Tuhan. ${ }^{106}$

Dengan demikian, firman Tuhan membuat umat Allah selalu melekat kepada-Nya dengan berkomunikasi melalui firman-Nya. Daud merenungkan Taurat telah menjadi sebuah sifat yang terus-menerus. ${ }^{107}$ Merenungkan Taurat Tuhan artinya sebuah kesediaan mempelajari, dikoreksi dan melakukannya dengan sungguh-sungguh. Seorang yang merenungkan dengan sungguh-sungguh akan mengalami perjumpaan, serta lahir sebuah kekaguman, hasrat terhadap firman Tuhan, seperti yang dialami raja Daud. Raja Daud mencintai dan merenungkan firman Tuhan oleh karena memahami pentingnya firman. Memahami pentingnya firman Tuhan mendatangkan sebuah intimasi hidup kepada Allah. Cinta kepada Tuhan adalah dasar yang membuat seseorang untuk berkomunikasi kepada Allah melalui firman-Nya. ${ }^{108}$

\section{Memberikan Kesetiaan dan Ketaatan (Ay. 98. 101)}

Intimasi hidup yang dimiliki raja Daud terhadap Taurat Tuhan melahirkan sebuah kesetiaan untuk senantiasa berpegang, memelihara seluruh hukum-hukum Tuhan. Kebenaran Taurat Tuhan senantiasa memberikan sebuah hasrat untuk senantiasa setia kepada pengajaran-pengajaran Allah.

Kata "selamanya" dalam Bahas Ibrani l'äA[l. dari kata dasar l'A[ (owlan) sepanjang waktu, sepanjang zaman, masa depan, keakanan, selamanya, abadi, tetap, kekal. Kata l'A[ (owlan) ditulis dalam bentuk conjunctive preposition org1 noun masculine singular. ${ }^{109}$ Merupakan kata penghubung awalan orang pertama tunggal. Arti selama-lamanya dihubungkan pada firman Tuhan. Firman tersebut akan selamalamanya melekat pada hidup Daud. Artinya Daud berjuang setia kepada Allah dan segala hukum-hukum-Nya. Jadi, Frasa "selama-lamanya itu ada padaku" menyatakan sebuah kesetiaan yang lahir oleh karena hubungan yang akrab dengan Allah.

Kata "memegang" dalam Bahasa Ibrani yTir>c")n" dari kata dasar rcn (natsar) ditulis dalam bentuk verb qal perfect 1st person common singular. ${ }^{110}$ Merupakan kata kerja aktiv yang dilakukan secara sempurna oleh orang pertama tunggal yaitu seorang yang merenungkan firman Tuhan. Arti kata yTir $>c$ ")n" ialah menjaga, memelihara, menyimpan, menerima, kunci, berhati-hati, melindungi, memperhatikan. Kata

105 Bermeditasi berarti memikirkan, mengunyah, merefleksikan, membayangkan, mempelajari, bergaul dengan mesra, bahkan juga mengeluh R. Laird Harris, Gleason L. Archer and Bruce K. Waltke, Theological Wordbook Of The Old Testament,..., 875

106 Daud merenungkan kasih Allah yang tidak pernah gagal, merenungkan semua karya Allah, mengingat-ingat semua perbuatan-Nya, merenungkan ajaran-ajaran-Nya, mengingat-ingat semua jalanNya, merenungkan hukum-hukum Allah sepanjang hari, serta merenungkan janji-janji-Nya.Mazmur 119: 59; 119: 15

Hanya sekedar memikirkan atau mempertimbangkan akan tetapi lebih mengarah kepada kesediaan untuk mempelajari setiap waktu, secara mendalam serta mengamati karya Allah secara mendalam, sedia memandang pada Allah secara sungguh-sungguh. Merenungkan dengan seluruh perhatian terhadap firman-Nya

108 Mazmur 119:97,107,109

109 John Joseph Owens, Analytical Key To The Old Testament,..., 480

110 Joy P. Green, The Interlinier Bible Hebrew-English, (Grand Rapids, Michigan: Baker House, 1976), 1508 
"yTir>c")n"” merupakan kata kerja aktiv biasa yang menyatakan suatu keadaan yang sudah selesai dilakukan orang pertama tunggal (Daud). Artinya sebuah keputusan yang telah dilakukan dengan sempurna. Kata "memegang" dalam Key word study bible ialah mematuhi, mentaati, menuruti, taat. ${ }^{111}$

Frasa "supaya aku berpegang" dalam terjemahan Key word study bible "so that I might obey your word". ${ }^{112}$ Kata "berpegang" dalam Bahasa Ibrani rmoðv.a, (isemar) berasal dari kata dasar rm; $v^{\prime}$ (shamar) ditulis dalam bentuk prepotition verb qal imperfect 1st person common singular. Kata rmoðv.a, merupakan suatu tindakan yang akan dilakukan oleh orang pertama tunggal secara aktiv sampai sempurna. Kata rm; $\mathrm{v}^{\prime}$ dalam TWOT ialah I keep, guard, observe, give heed. Makna dasar dari kata rm; $\mathrm{V}^{\prime}$ adalah berhati-hati, memberi perhatian, melestarikan, memelihara. Dalam kombinasi dengan kata kerja lainnya, artinya adalah lakukan dengan hati-hati atau tekun. ${ }^{113}$ Perlu dicatat bahwa ketaatan kepada hukum-hukum Allah tidak hanya menjadi masalah teori saja atau kepatuhan yang asal-asalan saja. Ungkapan berpegang memberikan makna yaitu harus disimpan di dalam hati. ${ }^{114}$ Dengan demikian, seorang yang memiliki intimasi kepada Allah akan senantiasa memegang titah-titah Tuhan.

\section{Sebab Engkaulah Yang Mengajar Aku (Ay. 102)}

Teks ini menjelaskan bahwa keintiman Daud kepada Allah lahir dari proses dimana Daud menyadari bahwa Allah memberikan pengajaran dan Allah mendidik Daud dalam terang firman-Nya. Pendidikan Allah dalam terang firman-Nya membuat Daud melekat, intim, bersatu, akrab dengan Allah.

Kata "mengajar" dalam Bahasa Ibrani ynlt" rEAh (hayarah) dari kata dasar hr'y" ditulis dalam bentuk hiphil perfect 2and masculine singular suffix. ${ }^{115}$ Hiphil menyatakan sebab akibat orang kedua maskulin merupakan perbuatan yang telah dilakukan dengan sempurna. Kata "mengajar" dalam NIV menggunakan kata "taugh". ${ }^{116}$ Istilah "taugh" diterjemahkan teach yaitu mengajar, melatih, menghajar. ${ }^{117}$ Kata "sebab" merupakan penyebab raja Daud tidak menyimpang dari hukum-hukum Tuhan oleh karena hukum-hukum Allah memberikan pengajaran. Maka yang membuat Daud memiliki tekad untuk tidak menyimpang dari hukum-hukum Tuhan dan memelihara keintimannya dengan Allah ialah Allah yang memberikan pengajaran.

\section{Firman Tuhan Membentuk dan Memberikan Karakter Sebagai Umat Tuhan}

111 Spiros Zodhiates, New International Version Hebrew-Greek Key Word Study Bible, (Chattanooga: AMG Publishers, 1996), 719

112 Spiros Zodhiates, Key Word Study Bible New International Version, (Chattanooga: AMG

Publishers, 1996), 718

113 Amsal 19: 8; Ulangan 11: 32: Bilangan 23: 12

114 R. Laird Harris, Gleason L. Archer and Bruce K. Waltke, Theological Wordbook Of The Old Testament,..., 939

115 John Joseph Owens, Analytical Key To The Old Testament,..., 480

116 Kenneth Barker, The NIV Study Bible New International Version,..., 919

117 John M. Echols dan Hassan Shadily, Kamus Inggris-Indonesia, (Jakarta: PT Gramedia Pustaka Utama, 1976) 580 
Setelah penulis meneliti dan melihat makna teks Mazmur 119: 97-106, penulis melihat adanya sikap hidup atau karakter yang diperoleh akibat mencintai firman Tuhan dan merenungkan firman Tuhan, ialah:

\section{Menahan Kaki Terhadap Kejahatan (Ay. 101)}

Tujuan Allah memberikan firman-Nya ialah agar umat-Nya memiliki sikap hidup, karakter hidup sebagai umat Tuhan. Karakter hidup sebagai umat Allah membuat Daud menjaga, memelihara, menguasai diri dan menjauhkan hidupnya dari dosa. Istilah menguasai diri dalam teks ini menggunakan kata menahan kaki.

Kata "menahan" dalam Bahasa Ibrani ytialiäK' dari kata dasa ra I'K' (kawlaw) hold sepenuhnya menguasai diri. Kata ytialiäK' ditulis dalam bentuk qal perfect $1 \mathrm{rd}$ common singular. ${ }^{118}$ Kata "memegang" dalam terjemahan NIV ialah menjaga, memelihara, menyimpan. ${ }^{119}$ Jadi, arti menahan kaki ialah menahan, menguasai dirinya terhadap hal-hal yang bertentangan dengan segala hukum-hukum Tuhan. Menahan kaki secara aktiv dan terus-menerus. Daud menahan kaki atau hatinya untuk membunuh Saul, oleh karena firman Tuhan mengingatkan Daud bahwa Saul adalah hamba yang diurapi Allah. ${ }^{120}$ Daud taat kepada firman Tuhan yang telah mengingatkannya untuk tidak membunuh hamba yang diurapi Tuhan. Daud memelihara hidupnya dari perbuatan dosa. Sehingga firman Tuhan mampu membuat Daud menguasai dirinya terhadap tindakan yang meluakai hati Tuhan.

\section{Tidak Menyimpang Dari Hukum-Hukum Tuhan (Ay. 102)}

Daud memiliki karakter hidup sebagai umat Tuhan, membuatnya memiliki sikap hidup atau komitmen untuk tidak melupakan dan meninggalkan hukum-hukum Tuhan. Sikap hidup sebagai umat Allah ialah senantiasa melakukan kebenaran dan tidak meninggalkan kebenaran.

Istilah "tidak menyimpang" dalam terjemahan rws (sur) verb qal perfect 1 st person common singular. ${ }^{121}$ Kata kerja aktiv tunggal yang dinyatakan telah selesai atau sempurna. Kata yTir $>s^{\prime \prime}+$ berasal dari kata dasar rws Arti kata rws (sur) belok, belok jauh, menarik jauh, berkunjung, condong, bergerak. ${ }^{122}$ Kata not turned aside dalam terjemahan KJV memakai kata not departed tidak meninggalkan, berangkat, pergi, menyimpang dari kebiasaan-kebiasaan yang dianut, bertolak. Hukum-hukum Allah mengajar untuk menimbang segala hal berdasarkan ketentuan-ketentuan Allah dan yang sebenarnya.

Dalam hukum Allah, mengajarkan bahwa anugerah Kristus adalah jalan menuju pengampunan dan kehidupan. Dalam hukum Allah, mengajarkan bahwa berlaku lemah lembut terhadap orang yang tidak berpengetahuan dan sesat adalah kewajiban umat

\footnotetext{
118 John Joseph Owens, Analytical Key To The Old Testament, ..., 480

119 Kenneeth Barker, The NIV Study Bible New International Version, ..., 919

120 I Samuel 24: 6

121 John Joseph Owens, Analytical Key TO THE Old Testament Vol. 3 Ezra-Song Of Salomon, (Michigan, Grand Rapinds: Baker Book House, 1993), 480

122 Spiros Zodhiates, The Hebrew-Greek Key Study Bible New American Standard, (Chattanooga: AMG Publishers, 1977), 82
} 
Tuhan. Hukum-hukum Tuhan adalah ketentuan hidup umat Tuhan yang memberikan hidup. Komitmen Daud untuk tidak menyimpang dari hukum-hukum Tuhan oleh karena Daud telah memilih firman Tuhan sebagai jalan yang menuntunnya kepada kebenaran Allah. ${ }^{123}$

Dengan demikian, Daud memilik tekad untuk tetap setia, taat terhadap hukumhukum Tuhan, berpegang pada undang-undang Tuhan yang didasari dari pengalaman yang Daud dapatkan dalam Taurat Tuhan. Bagi penulis alasan utama Daud tidak menyimpang dari hukum-hukum Tuhan ialah kecintaannya terhadap Taurat Tuhan. Perasaan cinta membuat setiap orang melekat kepada yang dicintainya dan melahirkan sebuah tekad untuk tidak menyimpang dari hukum Tuhan.

\section{Benci Segala Jalan Dusta (Ay. 104)}

Sebagai umat Allah, Daud memiliki komitmen untuk menjauhi segala jalan dusta. Firman Tuhan memberikan karakter hidup dan memampukan manusia membenci segala dosa.

Kata "benci" dalam Bahasa Ibrani ytianEÜf' (saneaty) dari kata dasar anf ditulis dalam bentuk verb qal perfect 1st person common singular "hate" rasa benci, kejahatan, tidak senang. ${ }^{124}$ Merupakan kata kerja aktiv biasa yang menyatakan suatu keadaan yang sudah selesai dilakukan orang pertama tunggal (Daud). Kata ytianEÜf' sangat membenci secara utuh. ${ }^{125}$ Kata "jalan" dalam Bahasa Ibrani xr:ao dari kata dasar xr:ao. ${ }^{126}$ construct noun common both singular construct (jalan, arah, jurusan, cara). Kata xr:ao merupakan kata benda umum tunggal yang dilakukan secara sungguh-sungguh. Both artinya keduanya (semua jalan dusta). Dalam terjemahan NIV menggunakan kata "path" jalan kecil, garis, tingkahlaku, sikap. ${ }^{127}$ Dalam terjemahan NASB menggunakan kata "way" (Jalan). ${ }^{128}$ Raja Salomo menegaskan bahwa dosa adalah noda bangsa. ${ }^{129} \mathrm{Jadi}$, ayat ini menjelaskan bahwa titah-titah Tuhan memberikan sebuah pengertian yang benar. Pengertian tersebut membuat Daud membenci, menjauhi segala jalan, cara, sikap yang tidak benar berdasar titah-titah Tuhan.

\section{Membuatku Bijaksana (Ay. 98)}

Allah memberikan hikmat dan kebijaksanaan kepada Daud oleh karena Daud bersedia memelihara dan melakukan firman Tuhan. Karakter hidup umat Allah ialah hidup bijaksana dan mampu mengelola keadaan. Orang yang bijaksana adalah orang yang memiliki kemampuan.

${ }^{123}$ Mazmur 119: 29-30

124 Joy P. Green, The Interlinier Bible Hebrew-English,.., 1508

${ }^{125}$ R. Laird Harris, Gleason L. Archer and Bruce K. Waltke, Theological Wordbook Of The Old Testament,..., 880

126 Joy P. Green, The Interlinier Bible Hebrew-English, ..., 1508

127 Kenneth Barker,The NIV Study Bible New International Version, (Grand Rapids Michigan: Zondervan Publishing House, 1985), 919

128 Thomas Nelson, The Open Bible New American Standard, (California: Thomas Nelson Publishers, 1977), 570

${ }^{129}$ Amsal 14: 34b 
Kata "bijaksana" dalam terjemahan Ibrani memakai kata ynlmEåK.x;T. (techakameni) ditulis dalam bentuk verb piel imperfect 3rd person feminine singular suffix 1st person common singular. Piel merupakan suatu penegasan. Suffix adalah kata penunjuk yang ditujukan pada perintah Allah. Kata ynlmEåK.x;T dari kata dasar $\sim$ kx (chakam) be wise, wisdom, make wise, teach wisdom, act wisely. ${ }^{130}$ Istilah $\sim \mathrm{kx}$ mengungkapkan sebuah kebijaksanaan. ${ }^{131}$ Istilah "hikmat" dalam terjemahan Ibrani menggunakan kata "khokhma" meskipun dipakai juga istilah lain bina "pengertian"132, tevuna "kebijakan". ${ }^{133}$ Pdt. Sri Wahyuni menuliskan:

Hikmat (bahasa Inggris: Wisdom adalah suatu pengertian dan pemahaman yang dalam mengenai orang, barang, kejadian atau situasi, yang menghasilkan kemampuan untuk menerapkan persepsi, penilaian dan perbuatan sesuai pengertian tersebut. Seringkali membutuhkan penguasaan reaksi emosional seseorang passions, supaya prinsip, pertimbangan dan pengetahuan universal dapat menentukan tindakan seseorang. Hikmat juga berarti pemahaman akan apa yang benar dikaitkan dengan penilaian optimal terhadap suatu perbuatan. Sinonim hikmat ialah kebijaksanaan, kecerdasan, akal budi, akal sehat, kecerdikan. Hikmat adalah kemampuan membuat akhir yang sempurna dan mencapai akhir itu melalui cara yang sempurna. ${ }^{134}$

Hokma artinya memberikan tuntunan. ${ }^{135}$ Kebijaksanaan dapat melakukan yang baik, adil dan yang benar. ${ }^{136}$ Daud meyakini bahwa ia menjadi lebih bijaksana, oleh karena kuasa firman-Nya. Pdt. DR. Gunaryo Sudarmanto mengatakan "Kebijaksanaan adalah tulus dan cerdik."137

Dengan demikian, Setiap orang yang sedia dipimpimpin, dikuasai, dikomandoi oleh perintah-Nya akan memperoleh kebijaksanaan. Bijaksana dalam segala hal, sebab roh yang didalam manusia dan nafas yang Mahakuasa itulah yang memberikan

130 Kata "wiser" berasal dari kata dasar Ibrani k;x' (chakam) bijak dalam pikiran, melebihi, mengajarkan kebijaksanaan, membuat diri cerdas, memiliki kemampuan.Spiros Zodhiates, The HebrewGreek key study bible New American Standard, (Chattanooga: AMG Publishers, 1997), 39

131 Terampil dalam pekerjaan teknis, bijak dalam urusan administrasi, bijaksana secara etis dan religius, bijaksana pikiran, takut akan Tuhan, guru yang bijak, berhikmat, menjadi manusia yang berkah bagi orang lain. Frances Brown, The New Hebrew And English Lexicon, (Indiana: Associated Publishers And Authors Inc Lafayette, 1978), 314-315

132 Ayub 39: 20

133 J. D. Douglas, Ensiklopedi Alkitab Masa Kini Jilid I A-L, (Yayasan Komunikasi Bina Kasih, 2002) 391-392

134 Sri Wahyuni, Journal Teologi Hikmat lebih besar dari pada keperkasaan, (Tanjung Enim, 2015), 106

135 Kata hikmat dijelaskan dalam beberapa istilah. Musar artinya disiplin., Leka pengajaran yang diterima, Tahbuloth bimbingan, penuntunn pedoman, Mashal pengertian, hokma kemampuan intelektual, Bina intelegensi, Orma ketajaman pikiran, Mizima kecerdasan, kebijaksanaan, Tusiyya kemampuan praktis atau kemampuan melakukan sesuatu. Barnabas Ludji, Pemahaman Dasar Perjanjian Lama, (Jabar: Bina Media Informasi, 2009), 182-183

136 1Raja-Raja 3

137 Kebijaksanaan itu tidak menyimpan kepahitan, jalannya lurus-lurus saja, setia pada yang diyakini, senang terhadap yang bersih Pdt. Gunaryo Sudarmanto, Kuliah Teologia Kepemimpinan Kristen, (Tanjung Enim, 05 April 2018) 
manusia kebijaksanaan. Sikap bijaksana yang diperoleh oleh karena perintah Tuhan membuat manusia takut dan menghormati Tuhan sebagai pencipta langit dan bumi. Raja Daud dengan penuh kekaguman mengatakan bahwa hanya perintah Tuhan yang mampu membuat manusia menjadi lebih bijaksana bahkan melebihi segala musuh. Bijaksana mampu bertindak berdasarkan pengalaman dan pengetahuan yang telah diperoleh di masalalu secara khusus pengalaman dalam firman Tuhan. Kebijaksanaan menolong manusia mampu menempatkan diri di dalam segala keadaan. Dengan mempelajari dan mempraktikkan perintah-perintah Allah, dan menjadikannya sebagai pemandu, raja Daud belajar untuk bersikap baik secara bijaksana dalam semua caranya. ${ }^{138}$ Jadi, kebijaksanaan yang dimiliki Daud oleh karena Daud bergaul dengan firman Tuhan. Kebijaksanaan yang bersumber dari Allah membuat Daud lebih cerdas daripada musuh-musuhnya atau mungkin mereka yang menjadi pengajarnya.

\section{Berakal Budi (Ay. 99)}

Daud mengalami banyak pergumulan dari orang-orang fasik yang senantiasa mencela hidupnya. Daud diperhadapkan dengan orang-orang yang menghina Taurat Tuhan. Komitmen Daud untuk senantiasa mencintai Taurat-Nya di dasari oleh Taurat Tuhan yang memberikan pengertian dan kedewasaan. Istilah pengertiandalam teks ini menggunakan kata berakal budi.

Kata "berakal budi" dalam Bahasa Ibrani yTil.K; f.hi (tisecalty) (understanding) berasal dari kata dasar $\mid k, f^{\prime}$ (sakal) ditulis dalam bentuk verb hiphil perfect 1st person common singular homonym. ${ }^{139}$ Verb hiphil adalah kata kerja yang menyatakan sebuah sebab akibat. Frasa "berakal budi" berasal dari dua kata "akal" dan "budi". Kata Ik;f' dalam TWOT ialah instruct, prudent. ${ }^{140}$ David Powlison menuliskan bahwa "akal budi yang sehat memberikan peneguhan yang jelas kepada Dia yang sikap dan tindakanNya menentukan". ${ }^{141}$

Dengan demikian, Dasar Daud memiliki akal budi ialah firman Tuhan. Firman Tuhan itulah yang membuat seorang menjadi pribadi yang berakal budi, memiliki watak yang baik, pikiran yang sehat dan kemampuan memahami keadaan. Akal budi menolong umat Tuhan berjalan dalam kehendak Tuhan. Sehingga dalam ayat ini tampak sebuah fakta bahwa akibat merenungkan peringatan Tuhan membuat raja Daud lebih berakal budi dari semua pengajar. Petrus Octavianus menuliskan bahwa, "karena akal budi yang gelap, maka firman Tuhan tidak lagi menjadi ukuran bagi setiap perbuatannya, mereka buta terhadap firman Tuhan". ${ }^{142}$

\section{Aku Lebih Mengerti Dari Orang-Orang Tua (Ay. 100)}

Hidup sebagai umat Allah memiliki tantangan, hal itulah yang dialami raja Daud dalam memimpin Bangsa Israel. Hadirnya orang-orang fasik yang menghina firman

\footnotetext{
1381 Samuel 18:14

139 Jay P. Green, The Interlinier Hebrew-Aramic Old Testament, ..., 27

${ }^{140}$ R. Laird Harris, Gleason L. Archer and Bruce K. Waltke, Theological Wordbook Of The Old Testament,..., 1079

141 David Powlison, Mengatakan Kebenaran Dalam Kasih, konseling Dalam Komunitas, 16

142 P. Octavianus, Rahasia kemenagan atas dosa, (Malang: Departemen Literatur Yayasan Persekutuan Pekabaran Injil Indonesia, 1978), 41
} 
Tuhan membuat Daud berharap pada firman Tuhan yang memberikan kedewasaan, pengertian bahkan pemahaman.

Kata "mengerti" dalam Bahasa Ibrani !n"+ABt.a, (etbonan) saya memiliki, memegang pengertian). ${ }^{143}$ John $M$. Echols memberikan pengertian kata "understanding"144 Daud menyadari bahwa hanya titah Tuhan yang mampu membuatnya lebih mengerti dari semua pengajarnya. Lebih mengerti artinya lebih dewasa, lebih memiliki pengalaman dalam konteks pengalaman firman Tuhan. Istilah "Titah-Mu" dalam terjemahan bahasa Ibrani menggunakan istilah $\wedge^{\wedge d<a ̈ W Q p i ~}$ (piqquwd) yaitu precept ajaran, petunjuk, pedoman, statua undang-undang, hukum, intructions arahan. Kata ${ }^{\wedge} \mathrm{yd}<$ äWQpi noun common masculine plural construct suffix. ${ }^{145}$ Merupakan kata benda dalam bentuk jamak yang tertuju pada titah Allah.

Dengan demikian, Firman Tuhan memberikan keunggulan yang lebih dari semua pengajar. Ungkapan semua pengajar mengacu kepada dosen, guru, instruktur, mentor, pelatih, pembimbing, pendidik, pengasuh, penyuluh. Teks ini sangat jelas memberikan pemahaman baru bagi semua orang bahwa hanya firman Tuhan yang membuat manusia menjadi lebih dewasa. Penekanan utama ialah mengutamakan firman Tuhan sebagai sumber pengetahuan dan pikiran yang baik bukan pada akal pikiran seperti yang diandalkan orang sekuler. Mungkin secara intelektual guru lebih berilmu, tetapi belum tentu lebih dewasa, berpengertian dari seorang yang hidup bergantung berdasarkan peringatan-peringatan Allah.

\section{Aku Beroleh Pengertian}

Kemampuan untuk memahami kehendak Allah ialah melalui pengertian yang terdapat di dalam firman Tuhan. Sebab firman Tuhan membuat umat Allah memiliki pemahaman, dan kemampuan untuk mempertimbangkan segala hal dengan baik. Firman Tuhan memberikan penerangan hidup kepada umat agar senantiasa memandang kepada firman-Nya.

Istilah "aku beroleh pengertian" dalam terjemahan Bahasa Ibrani menggunakan istilah !n"+ABt.a, berasal dari kata dasar !yb verb hithpolel imperfect 1st person common singular. Kata !n"+ABt.a, (etybinan) memiliki beberapa pengertian dasar "I get understanding" (aku lebih mengerti, discern memahami, melihat dengan jelas, discerning, consider mempertimbangkan, memperhitungkan, memikirkan perasaan orang lain, menganggap, memandang. ${ }^{146}$ Pengertian itulah yang membuat Daud lebih mempertimbangkan, memikirkan perasaan Tuhan dan hukum-hukum-Nya.

Dengan demikian, Titah Tuhan adalah dasar utama raja Daud membenci segala jalan dusta. Maka dalam ayat ini tampak sebuah akibat seorang yang hidup berdasarkan titah Tuhan akan melahirkan sebuah komitmen untuk membenci semua hal yang tidak disukai oleh Allah. Dalam (Kejadian 39: 9b) Yusuf sangat membenci

${ }^{143}$ Frank E. Gaebelein, The Expositoris Bible Commentary Volume 5, (Grand Rapids, Michigan: Zondervan Publishing House, 1991), 753

${ }^{144}$ Yaitu keadan seseorang yang mencapai tujuan, telah mencapai umur yang telah dimengerti atau dewasa, suatu sikap yang dapat mengerti akan orang lain. John M. Echols dan Hassan Shadily, Kamus Inggris Indonesia, 615

145 John Joseph Owens, Analytical key to the old testament vol 3 Ezra-Song of Salomon, ..., 480

146 John Joseph Owens, ..., 480 
segala perbuatan dosa, maka Yusuf mampu menolak godaan istri potifar oleh karena Yusuf memiliki pengertian yang benar terhadap titah-titah Tuhan. Faktor utama penyebab raja Daud membenci perbuatan dosa ialah pengertian yang diperoleh berdasarkan titah-titah Tuhan.

\section{Aku Telah Bersumpah Dan Aku Akan Menepatinya (Ay. 106)}

Daud memiliki kerendahan hati yang murni, dan kejujuran yang mendasar, yang mempunyai ketulusan. Dalam Bahasa Ibrani digunakan kata Thamam yang berarti sebuah ketulusan (integritas): lengkap, murni, tidak bersalah, memiliki hidup yang sederhana, sehat, dapat diandalkan dan tidak bercacat. ${ }^{147}$

Frasa "aku telah bersumpah" dalam Bahasa Ibarani yTi [.B;îv.nl (nisebaaty) dari kata dasar [b; $v$ ' shaba (I have sworn) saya memegang janji dan sumpah. ${ }^{148}$ Kata yTi[.B;îv.nl ditulis dalam bentuk niphal perfect common singular. ${ }^{149}$ Niphal mempunyai arti reflektif yang menunjuk pada diri sendiri, menunjukkan suatu keadaan yang telah dilakukan dengan sempurna. Sehingga kata [b;v' dalam bentuk niphal menunjuk pada diri sendiri. ${ }^{150}$ Frasa "aku akan menepatinya" dalam Bahasa Ibrani hm'YE+q;a]w" dari kata dasar $\sim$ Wq (I will comfirm it). ${ }^{151}$ Confirm artinya menegaskan, memperkuat. ${ }^{152}$ Arti kata $\sim$ Wq ialah penerapan, ketekunan, memelihara, menghidupkan, meningkatkannya, menjadikan, yang tidak bisa dipungkiri. ${ }^{153}$ Arti kata $\sim$ Wq dalam TWOT berdiri, bangkit, berpendirian tetap, memiliki hakikat hidup, berada. Arti menepati bukan hanya menggenapi dalam janji akan tetapi lebih mengarah kepada penerapan secara praktis yang disertai dengan ketekunan, menghidupakannya, memelihara dan menjadikannya sebagai gaya hidup. ${ }^{154}$

147 Ketulusan (integritas) adalah keadaan seseorang untuk tetap melakukan apa yang benar ketika tidak ada orang yang melihat, artinya ia adalah seseorang yang benar-benar jujur. Integritas Daud juga tampak pada komitmen Daud untuk melakukan Taurat Tuhan. Charles R. Swindoll, Seri Tokoh Terbesar: Daud,..., 24

148 Jay P. Green, The Interlinear Bible Hebrew-English, (Grand Rapids: Michigan, 1981),..., 1508

149 John Joseph Owens, Analitycal Key To The Old Testament,.., 481

150 James Strong, The Exhaustive Concordance Of The Bible,..., 112

151 John Joseph Owens, Analytical Key To The Old Testament,..., 481

152 Jhon M. Echols dan Hassan Shadily, Kamus Inggris Indonesia, ..., 137

153 James Strong, Strong's Exhaustive Concordance Of The Bible, 102

154 R. Laird Harris, Gleason L. Archer and Bruce K. Waltke, Theological Wordbook Of The Old Testament,..., 1067 